\title{
STUDY OF SOME WOOD-CHARCOAL CHARACTERS PRODUCED FROM SOME TREE SPECIES OF DUHOK PROVINCE
}

\author{
Dilgash FayeqYaseen ${ }^{*}$, Mohammedamin Yasin Taha ${ }^{*}$, Hasan Saleem Nabi ${ }^{* *}$ \\ and ABDULAZIZ JAMEEL YOUNIS* \\ *Dept. of Forestry, College of Agricultural Engineering Science, University of Duhok, \\ Kurdistan region- Iraq. \\ *** Dept. of Horticulture, College of Agricultural Engineering Science, University of Duhok, \\ Kurdistan region- Iraq
}

(Received: August 16, 2020; Accepted for Publication: September 13, 2020)

\begin{abstract}
This investigation was done in the laboratory of college of agricultural engineering sciences University of Duhok to study some wood-charcoal quality produced from some local wood species in Kurdistan region Iraq. In market, the quality of wood charcoal produced from tree species is varied due to divers' anatomical structure and carbonizing temperature process. As a consequence, understanding the factors controlling the quality of wood charcoal is an important issue for both producers (sellers) and consumers (buyers). In most charcoal factories, wood charcoal are produced without determining of their quality whereas each quality of wood charcoal has its own properties, price and uses. The quality of charcoal made from some selected local wood species (Quercus aegilops, Salix alba, Malus domestica, and Populus alba) were evaluated. The woods species were collected from Zaxo district of Duhok province and were transformed into wood-charcoal using a steel kiln for pyrolysis. The analysis of physical and chemicals such moisture content percentage [MCP], volatile matter percentage [VMP], ash content percentage $[\mathrm{ACP}]$ and fixed carbon percentage $[\mathrm{FCP}]$, of the produced wood-charcoal were proximately resolved using the (ASTM D3176 - 15) method. The results showed, for the first time on all around the Kurdistan region of Iraq, the quality of wood charcoal produced from these wood species. The highest value off moisture content (2.375\%) was with Malus domisteca as compared with Populus alba which was (1.000\%), highest volatile matter (21.125\%) was with Quercus aegilpops compared with Populus alba (4.125\%), high ash content recorded $(4.875 \%)$ with Quercus aegilpops compared with Salix alba (2.250\%) and the fixed carbon was greater value in Populus alba which was $(\mathbf{9 2 . 1 2 5 \% )}$ ) compared with Quercus

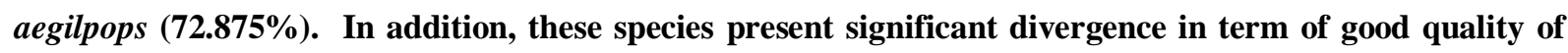
wood charcoal and the (populous alba) gave the superior quality of wood charcoal from the rest wood species. Therefore, the results of this study have a high assessment for managers of Kurdistan governmental and private charcoal factories as a suggestion which wood species is suitable in order to achieve better quality of wood charcoal.
\end{abstract}

KEYWORDS: Wood Characteristic, Charcoal, Physical, Chemical, Quality

\section{INTRODUCTION}

A 11 over the world, demand for energy has exacerbated human dependence on natural resources (Balatsky et al,. 2015). More than $50 \%$ of wood-from forests worldwide is used for energy production (Dam J. V. 2019). Recent advances in knowledge about the production and properties of charcoal presage its expanded use as a renewable fuel, reductant, adsorbent, and soil amendment (Antal, \& Grønli, 2003).

Charcoal is the residue of solid carbon complying with the pyrolysis (carbonization) of some carbonaceous raw materials. Charcoal is utilized basically as fuel for outdoor cooking and heating. (Moscowitz, 1978). However, woodcharcoal is in high demand as it includes energy that duplicates that of frequent firewood and hence burns much hotter, in addition wood- 
charcoal is cheap, easily available and very affordable compared to other energy sources like electricity, cooking gas and kerosene (Ekouevi, \& Tuntivate, 2011). Pyrolysis at $400^{\circ} \mathrm{c}$ the conversion of the wood to wood-charcoal is efficiently complete, the wood-charcoal at this temperature still involves an appreciable sum of tar, conceivably $30 \%$ by weight entrapped in the structure, this soft burned woo-charcoal needs distant heating to force off extended of the tar and therefore raise the content of fixed carbon of the wood-charcoal to around $75 \%$ which is typical for good quality commercial woodcharcoal (Booth, 1983).

Concerning charcoal quality, superior chemical features of wood-charcoal like high levels content of fixed carbon and lower levels content of volatiles and ash are allied with high lignin levels and low levels of extractives and holocelluloses in wood (Dos Santos et al,. 2011)

Oak (Quercus aegilops), a genus below the family of Fagaceae, is a group of hardwood trees. Oak spp. is found in zones of northern temperate, tropical, subtropical and Southern America (Shrestha 2003). This tree grows in areas with 650-2700 meter above the sea level, at temperature between $-31 \mathrm{C}^{\circ}$ to $+45 \mathrm{C}^{\circ}$ and rainfall between 250 to $900 \mathrm{~mm}$ (Saffarzadeh $e t$ al. 2000).

Salix alba L. (white willow) is a fast growing hardwood tree. It is one of the largest of the salix species and can reach heights of up to 30 meter and a diameter of 1 meter or more (Isebrands \& Richardson, 2014). It is usually surviving only 20 to 30 years (Praciak, et al. 2013).

Apple tree (Malus domestica under family of Rosaceae Juss.) is a global cultivated fruit tree. The originality homeland of this tree is Central Asia, where its antecedent Malus spp. is still growing wild. The apple tree could reach 3 to 12 meter in height P. (Judžentiené \& Misiūnas, 2017).

Populous alba (White Poplar) is a fast growing, hardwood tree that reaches $60-100$ feet in height with a 40 - 50 foot spread and build a nice shade, neither it is determined short lived. (Edward \& Watson, 1994).

The Aims of this study are to study the rate of fixed carbon, ash and volatile matter is commonly selected species which are responsible for a better burning and calorific value, evaluating the quality of wood charcoal made from selected species, comparison between the selected species and find out the best quality among these species, this would help the factories of charcoal producers to determine the best quality of the species and might encourage them to establish a laboratory for testing wood charcoal quality before sending to market and sellers whereas each quality have its own price, and finally to help the buyers and consumers to select the good quality of wood charcoal easily.

\section{MATERIAL AND METHODS}

\subsection{Wood-charcoal samples collection and preparation}

The most common wood species used were: (Quercus aegilopsL., Populus alba, Salix alba, and Malus domestica) from Zaxo district in Duhok province. The charcoal samples after being carbonized at $350{ }^{\circ} \mathrm{C}$ were collected from the BARY MAZI factory of charcoal production in the Duhok province of the Kurdistan region. All wood-charcoal samples were collected in polyethylene bags and afterward taken to laboratory where the samples were prepared, milled, particles that passed through a No. $20(850-\mu \mathrm{m})$ sieve and retained on a No. 100 $(150-\mu \mathrm{m})$ sieve were taken as showed in fig. (1), and stored in air tight plastic bags before taking for analysis of combustion and fuel-related parameters (ASTM D410-84 1988).

\section{The analysis of wood-charcoal samples}

The (BS EN ISO 18134-2:2017) method was used for moisture content, where $1 \mathrm{gm}$ of the wood-charcoal sample was placed into a suitable crucible, which was then dried at $105{ }^{\circ} \mathrm{C}$ for 2 hours to constant weight and the total moisture/dry solid contents were calculated from the reduction in weight as showed in fig. (1).

(ASTM D3176 - 15 2015) the standard method was practiced for volatile matter, where a dried wood-charcoal sample was placed in a suitable crucible with a close-fitting lid. The crucible and wood-charcoal samples were weighed and heated in a muffle furnace at a temperature of $900{ }^{\circ} \mathrm{C} \pm 10{ }^{\circ} \mathrm{C}$ for 7 minutes. Cool the crucibles with lids in place in desiccators for 1 hour and reweigh as showed in fig. (1).

(ASTM D1102 - 84. 2013) method was used for Ash-Place the lids and the crucible, and containing the sample in the furnace at $750^{\circ} \mathrm{C}$ for 6 hours. Cool the wood-charcoal samples in 
crucibles with lids in a desiccator for 1 hour and weight as showed in fig. (1).

The percentage of fixed carbon [PFC] contents of the samples were estimated by deducting the sum of (VMP), (ACP) and (MCP) from 100 as presented in equation (1) (ASTM D3180 - 15 2015):

The Fixed carbon content $=[100-(\mathrm{VM} \%+$

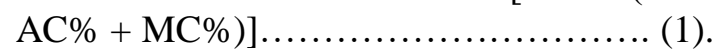

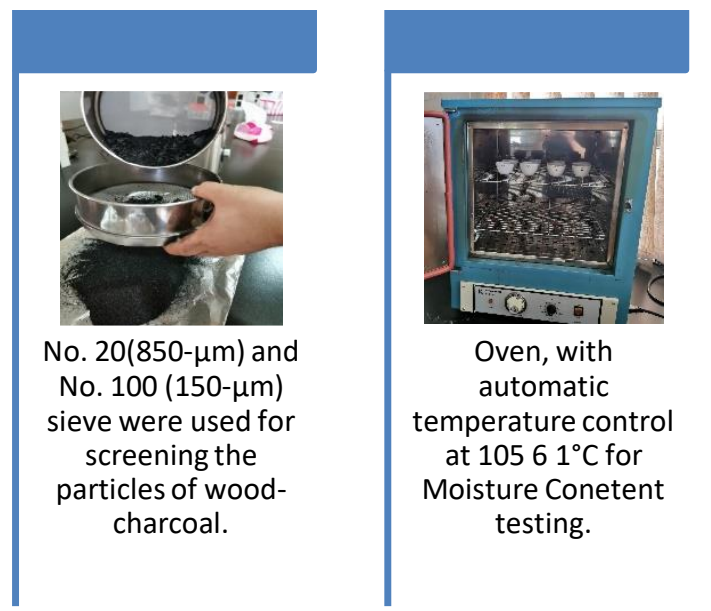

This study was calculated by using complete Randomize Design (CRD), there were four treatments with eight replications for each experimental units of wood-charcoal species were taken for analyzing by SAS program (SAS Institute 2015). And the mean of treatments were analyzed by multiple range test Duncan's (Al-Rawi, K. M., \& Khalafalla, A. 2000)

Fig. (1): The equipment that used for analyzing the wood-charcoal samples.

\section{RESULTS AND DISCUSSIONS}

Table (1): Mean values of charcoal moisture content, volatile matter, ash content and fixed carbon, four species of tree

\begin{tabular}{ccccc}
\hline Tree species & Moisture content (\%) & Volatile matter (\%) & Ash content (\%) & Fixed carbon (\%) \\
\hline Quercus aegilops L. & $1.125 \mathrm{~b}$ & $21.125 \mathrm{a}$ & $4.875 \mathrm{a}$ & $72.875 \mathrm{~d}$ \\
\hline Salix alba & $1.250 \mathrm{~b}$ & $20.375 \mathrm{~b}$ & $2.250 \mathrm{c}$ & $76.125 \mathrm{c}$ \\
\hline Malus domestica & $2.375 \mathrm{a}$ & $13.500 \mathrm{c}$ & $3.000 \mathrm{~b}$ & $81.125 \mathrm{~b}$ \\
\hline Populus alba & $1.000 \mathrm{~b}$ & $4.125 \mathrm{~d}$ & $2.750 \mathrm{bc}$ & $92.125 \mathrm{a}$
\end{tabular}

Means of each Species in columns followed with the same letters are not significantly different from each other's according to Duncans multiple range test at $5 \%$ level.

\subsection{Percentage of Moisture Content}

Chemical properties of wood-charcoal revealed significant variance among the different species of wood-charcoal in this analysis. WoodCharcoal made from Malus domestica wood specie significantly had the highest value of moisture content $(2.374 \%)$, charcoal from Salix alba wood had $(1.250 \%)$, charcoal from Quercus aegilops wood specie had $(1.125 \%)$; while wood-charcoal by Populus alba wood specie had the lowest value of moisture content $(1.000 \%)$ respectively. This is because the high content of moisture make fines and lowers the calorific of wood-charcoal (FAO, 1985). This was because of the nature of water absorbing and low grade of halocelluloses of Oak trees (Stimely \& Blankenhorn, 2007). The moisture content values of wood-charcoal manufactured 
from various wood species utilized for these analysis reached the acceptable criteria by (FAO, 1985) that the highest limit for moisture content is $7 \%$.

\subsection{Percentage of Volatile Matter}

Volatile matter percentage in wood-charcoal of Quercus aegilops specie introduced distinctly the highest proportion $(21.125 \%)$ which had close percentage volatile matter to charcoal from Salix alba wood was $(20.375 \%)$. Charcoal from Malus domestica wood, had percentage volatile matter proportions of $(13.500 \%)$. Charcoal from Populus alba wood revealed the lowest volatile matter value $(4.125 \%)$. Table 1 shows the variance between different charcoal samples. The volatile matter in wood-charcoal could be differ from a higher value of $40 \%$ to a low value of 5\% (FAO, 1985). According to (Oliveira, 1990) regarding wood-charcoal quality, low levels of volatile matters in wood-charcoal are allied with higher lignin level and lower extractives levels of wood species. This was liable for Quercus aegilops specie that had more extractives between the different wood samples picked for the manufacturing of wood-charcoal and Populus alba specie had the lowest. The High value of volatile matter in wood-charcoal is lighting easily but maybe burn with a smoke while charcoal with lower volatility is hard to ignite and burn clean, however higher volatile matter in wood-charcoal is favoured for some uses like barbecue, while for other uses like purification of chemical and metal production need wood-charcoal with lower content of volatile matter, a good commercial woodcharcoal can have a net content of volatile matter (moisture-free) of around 30\%. High volatile matter wood-charcoal is nether friable than normal hard burned low volatile wood-charcoal and so makes fewer fines whiling transport and handling. The volatile matter other than water in charcoal comprises all those liquid and tarry residues not fully forced off in the process of carbonization. If the time and temperature of carbonization are increases, then the volatiles matter content is low and vice versa (Vahrman, 1987).

\subsection{Percentage of Ash Content}

Percentage ash content in different woodcharcoal had a significant difference. WoodCharcoal of Quercus aegilops wood (4.875 \%) had the higher value and a close proportion value of ash content with charcoal of Malus domestica wood (3.000\%), while wood-charcoal of Populus alba and Salix alba species had low ash content values of $(2.750 \%)$ and $(2.250 \%)$ respectively. According to (Tsoumis, 2009), the presence of high rate of mineral matter in woods is not profitable, whereas they are not degrading whilst carbonizing and they prevail in charcoal as an unacceptable residues that also assist to the lowering of charcoal calorific value. The variation in ash content percentage of woodcharcoal samples is showed in Table1. The ash content of wood-charcoal differ from around 0.5 $\%$ to $5 \%$ or more, which depends on the wood species used to make the wood-charcoal. A good quality wood-charcoal specifically has a value ash content about 3\% (FAO 1985). Fine woodcharcoal may have a very high ash content, buyers naturally suspect fine wood-charcoal and it is difficult to sell and use, unfortunately. (Vahrman, 1987).

\subsection{Proportion of Fixed Carbon}

There is a significant variance in the portion of fixed carbon between charcoal samples used and the highest portion of fixed carbon were in Populus alba species (92.125\%). Charcoal samples from Malus domestica specie had fixed carbon content value $(81.125 \%)$. Charcoal samples from Salix alba specie had fixed carbon content value $(76.125 \%)$. Charcoal from Quercus aegilops specie had the lowest fixed carbon content value of $(72.875 \%)$. The difference in fixed carbon percentage is shown in Table 1. The content of fixed carbon of woodcharcoal ranges from a low of 50\% to a high about 95\% (FAO 1985). According to Dos Santos (2011) on charcoal quality, superior chemical properties of charcoal such as high grades of fixed carbon are allied with high grades of lignin and low grades of extractives and holocelluloses in wood. The proportion of fixed carbon could be controlled by increasing temperature and time of the carbonizing process (Hindi, 1994). Increasing content of the fixed carbon of wood-charcoal in this method is allied with a decreasing the yield of charcoal (Vahrman, 1987).

\section{CONCLUSIONS}

This research was executed to evaluating the physical and chemical features of charcoal produced from some picked local wood species. The quality of charcoal that manufactured from populous alba woods was higher than other species, it has the lowest percentage of moisture content, low ash content and highest fixed carbon value. It is followed by charcoal manufactured from Malus 
domestica specie. There was little variance in the quality of charcoal from other wood species. The manufacturing and uses of charcoal from different wood species should be given wide broadcasting in Kurdistan due to the impending woods shortage and deficiency of other sources of non renewable energy. It was determined that the carbonized process at degree $350{ }^{\circ} \mathrm{C}$ is enough to produce a good quality of wood charcoal and if the temperature of carbonizing process raise to $400-450^{\circ} \mathrm{C}$ the quality of wood charcoal will be at a high level.

\section{REFERENCES}

Al-Rawi, K. M., \& Khalafalla, A. (2000). Analysis of Experimental Agriculture Design. Dar AlKutub for Printing and Publishing. Mosul Univ. Iraq (in Arabic). pp, 488.

Antal, M. J., \& Grønli, M. (2003). The art, science, and technology of charcoal production. Industrial \& Engineering Chemistry Research, 42(8), 1619-1640.

ASTM D1102 - 84. (2013). Standard Test Method for Ash in Wood.

ASTM D3176 - 15. (2015) Standard Practice for Ultimate Analysis of Coal and Coke

ASTM D3180 - 15 (2015) Standard Practice for Calculating Coal and Coke Analyses from AsDetermined to Different Bases

ASTM D410-84 Method of Sieve Analysis of Coal (Withdrawn 1988)

Balatsky, A. V., Balatsky, G. I., \& Borysov, S. S. (2015). Resource demand growth and sustainability due to increased world consumption. Sustainability, 7(3), 3430-3440.

Booth, H. E. (1983). Charcoal in the Asia and Pacific Region-problems and possibilities. In FAO/ESCAP Workshop on Charcoal Production and Technology, Bangkok (Thailand), 31 May 1983.

BS EN ISO 18134-2. (2017). Solid biofuels. Determination of moisture content. Oven dry method. Total moisture. Simplified method

Dam, J. V. (2017). The charcoal transition: greening the charcoal value chain to mitigate climate change and improve local livelihoods. The charcoal transition: greening the charcoal value chain to mitigate climate change and improve local livelihoods.

Dos Santos, R. C., Carneiro, A. D. C. O., Castro, A. F. M., Castro, R. V. O., Bianche, J. J., de Souza, M. M., \& Cardoso, M. T. (2011). Correlation of quality parameters of wood and charcoal of clones of Eucalyptus. Scientia Forestalis, 39(90), 221-230.
Edward F. G. and Watson D. G. (1994). Populus alba White Poplar. Fact Sheet ST-499.

Ekouevi, K., \& Tuntivate, V. (2011). Household energy access for cooking and heating: Lessons learned and the way forward. Energy and Mining sector board discussion paper, (23).

Food and Agriculture Organization of the United Nations- FAO (1985). Industrial charcoal making, FAO Forestry Paper No. 63, FAO, Rome.

Hindi, S. S. (1994). Charcoal properties as affected by raw material and charcoaling parameters (Doctoral dissertation, M. Sc. Thesis, Forestry Dept. Faculty of Agriculture, Alexandria University, Egypt).

Isebrands, J. G., \& Richardson, J. (Eds.). (2014). Poplars and willows: trees for society and the environment. CABI.

Judžentienè, A., \& Misiūnas, A. (2017). Chemical composition of apple-tree (Malus domestica Borkh.) leaf essential oils. Chemija, 28(3), 172-176.

Moscowitz, C. M. (1978). Source Assessment: Charcoal Manufacturing: State of the Art (Vol. 1). Environmental Protection Agency, Office of Research and Development, Industrial Environmental Research Laboratory.

Oliveira, E. (1990). Correlations between quality parameters of Eucalyptus grandis (Whill exMaiden) wood and charcoal. Technical Bulletin SIF, 2.

Praciak A., et al., (2013) The CABI encyclopedia of forest trees. CABI, Oxfordshire, UK.

Saffarzadeh, A., Vincze, L., \& Csapó, J. (2000). Determination of some anti-nutritional factors and metabolisable energy in acorn (Quercus branti), Pistacia atlantica and Pistacia khinjuk seed as new poultry diets. Acta Agraria Kaposváriensis, 4(1), 41-47.

SAS Institute. (2015). Base SAS 9.4 procedures guide. SAS Institute.SAS Institute.

Shrestha, B. B. (2003). Quercus semecarpifolia Sm. in the Himalayan region: Ecology, exploitation and threats. Himalayan Journal of Sciences, 1(2), 126-128.

Stimely, G. L., \& Blankenhorn, P. R. (2007). Effects of species, specimen size, and heating rate on char yield and fuel properties. Wood and Fiber Science, 17(4), 477-489.

Tsoumis, G. (2009). Science and technology of wood: structure, properties and utilization. Science and technology of wood: structure, properties and utilization.

Vahrman, M. (1987). Charcoal made in the pit-tumulus type of earth-kiln. International journal of energy research, 11(1), 133-143. 
خاندنا هنده ساخله تيّن رهزييا دارى هاتينه بهرههم ئينان ز هنده جوريّن داريّن د ناق ياريّزكه ها دهوكي

يوخته

ئهث ثه كولينه د لابورا كوليَّرا زانيّستيّن ئهندازياريا جاندنى ل زانكويا دهوك زبو ههلسهنگاندنا جورييا رهزييا دارى يا هاتيه بهرههمئينان ز هندهك جوريّن دارا كو ل ههريّما كوردستانا عيّراقيّ هاتيه كرن. دناق

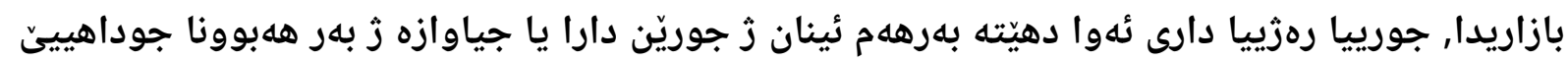

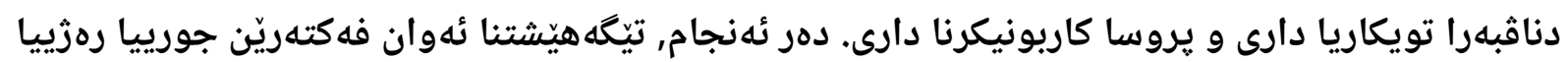

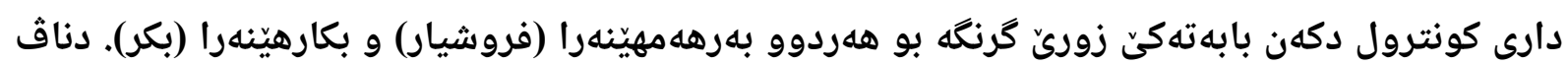

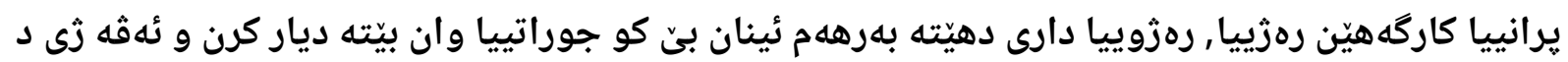

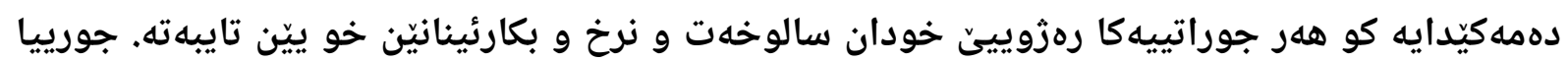

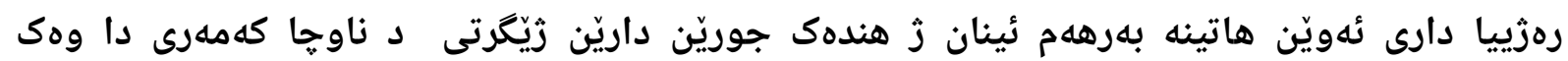

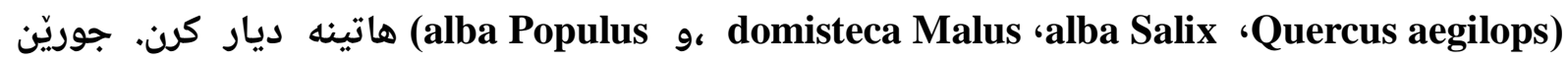
دارا هاتينه كومكرن ل قهزا زاخو ل ياريزّكها دهوكي و هاتينه گوهارتن ز بو رهزويى ب ريّكا بكارئينانا

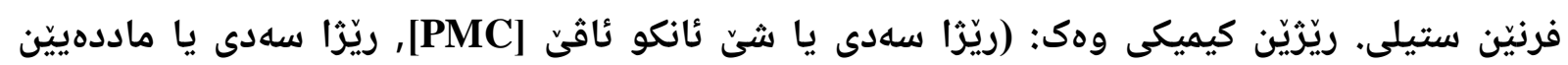
ههلمزى [PVM], ريّزا سهدى يا يِيّكهاتا خوولييّ [PAC] دناق رهزييّن بهرههم هاتى, نزيك كرى هاتنه دياركرن بكارئينانا ريّكا (15 - ASTM D3176). ثئنجاميّن

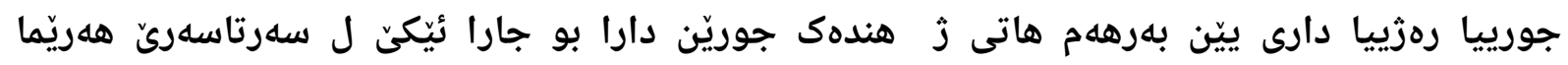

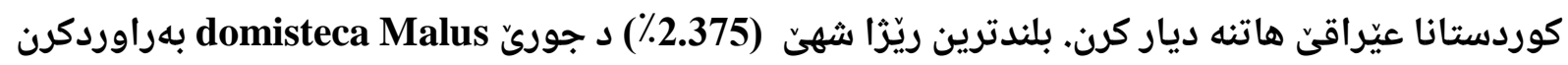

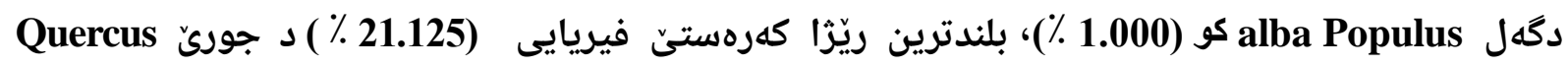

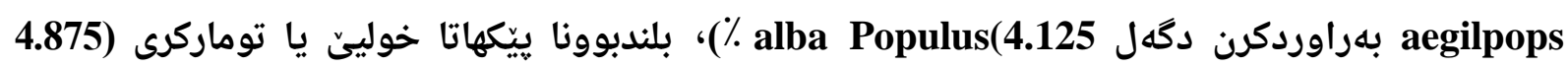

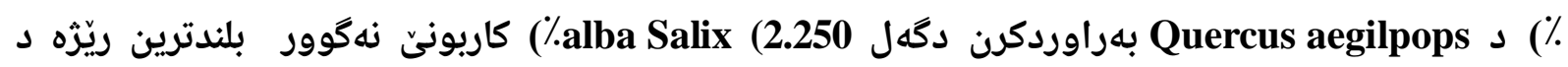
alba Populus

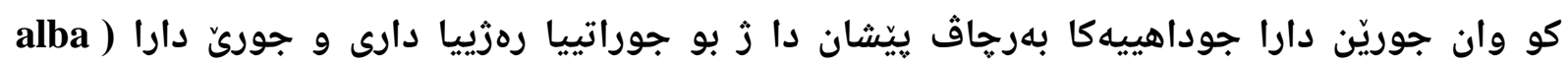

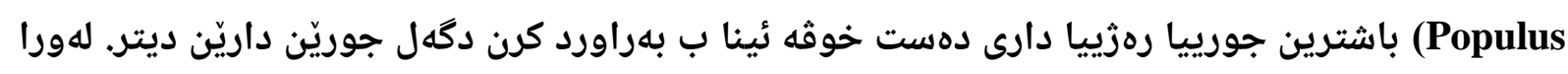

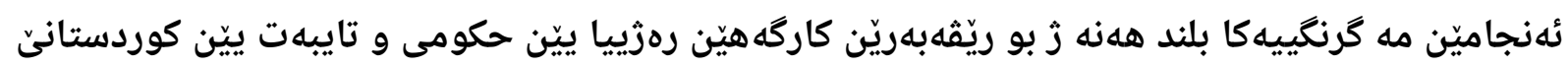

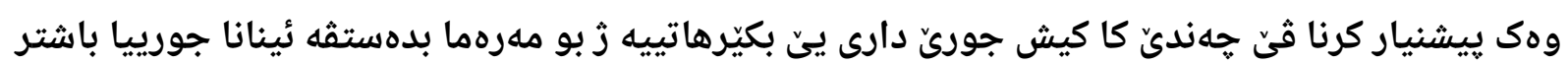
ييّن رهزييا دارى. 
دراسة بعض صفات الفحم الخشب المنتوجة من بعض أنواع أشجار في محافظة الدهوك

الخلاصه - الخه

تم إجراء هذه الدراسة في مختبرات كلية علوم الهندسة الزراعية في جامعة دهوك وذلك لتقييم جودة الفحم الخشبي المنتج من بعض أنواع الخشب المحلي في إقليم كوردستان العراق. في الاسواقر جودئ جودة الفحم الخشبي المنتج من الانوع الاخشاب المحلية تختلف عن بعضها الابعض وذلكي الكي بسبب التهب التركيب التشريحي للخشب وعملية الكربنة التي يتم فيها صنع الفحم الخشبي. ونتيجة لذلك، يعد فهم العوامل التي لإني تتحكم في نوعية الفحم الخشبي من المسال الهامة بالنسبة لجميع المنتجين (البائعين) و المستهلكين

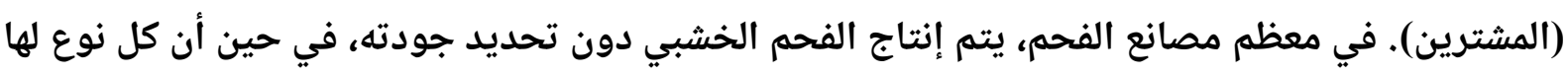

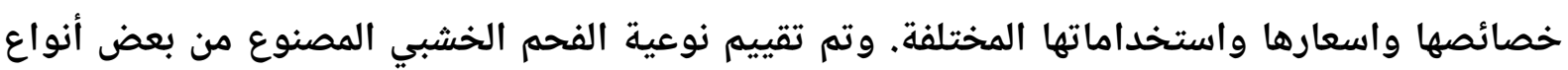

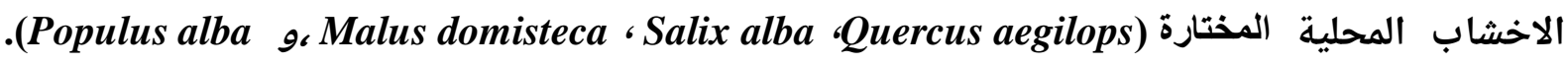
وقد تم جمع هذه الأنواع من الاخشاب في منطقة زاخو من محافظة دهوك، وتم تحويلها إلى الفحم

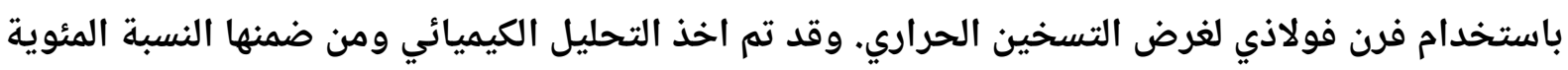

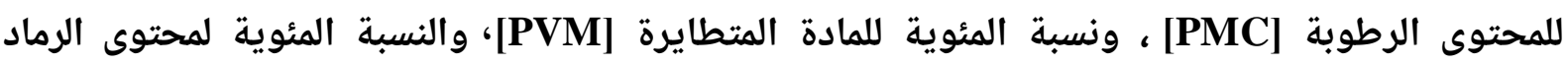

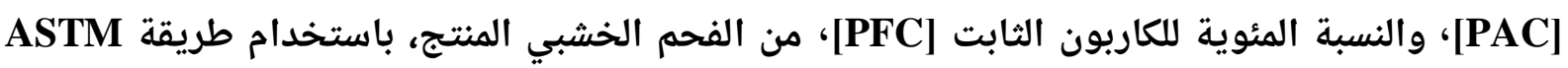

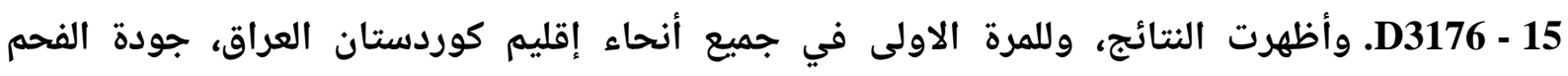

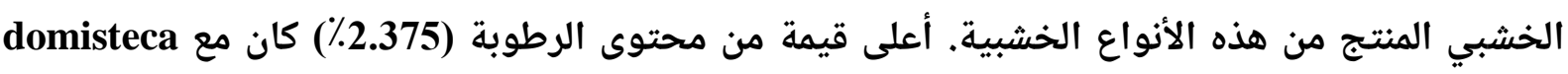
Malus مقارنة مع Quercus aegilpops

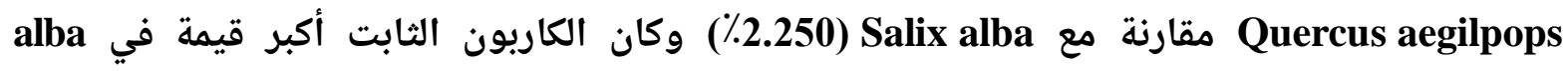

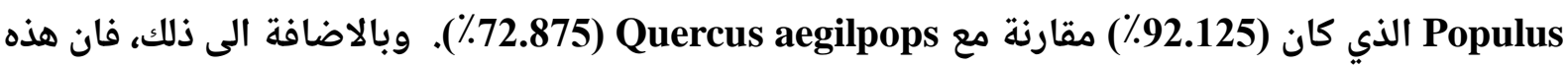

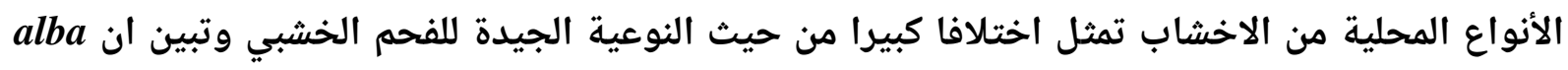

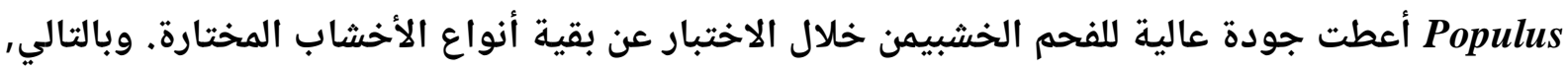
فان نتائج هذه الدرسة لها تقيم وتأثير عال لمديري المصانع الفحم الحكومية و كذلك الاهلية على حدا سواء الفاء في اقليم كوردستان و العراق كمعيار لاختيار النوع الانسب للاخشاب من اجل تحقيق جودة افضل للفحم 